\title{
DE DE GRUYTER OPEN \\ The Myth of the Angry Voters: Parliamentary Election in Slovak Republic
}

\author{
Viera Ž́úborová ${ }^{1}$ \\ Ingrid Borarosová ${ }^{2}$
}

\begin{abstract}
The recent parliamentary elections which took place in The Slovak Republic in March 2016 opened for many national and international commentators the bottled of demons from the past history of Slovakia. For the first time a Far right extremist political party entered into parliament and held seats there. They gained more than some standard political parties and also were not dubbed as the "black" horse of this election. As they were not measured by public opinion. The main purpose of this article is to analyze the fundamental purpose of voters that had elected this political party and on the other hand the main reason that has opened the parliamentary door to such a political entity that was not visible in the previous electoral periods or played any important role in the independence of Slovak republic. Our main assumption will be that which is taken from the media analysis before the parliamentary election and public opinion research. Our main variable from the external environment will be the migration refugee crisis and the rhetoric of political parties acting at national level. We can assume that this was one of the main reason for the entry of this political party within others which were "hidden" or covered by this crisis and were not mediatized in the media.
\end{abstract}

Key words: parliamentary election, extremist right political party, media, migration - refugee's crisis

\section{INTRODUCTION}

The last parliamentary elections in The Slovak republic were seen as one which created a shift in the thinking of policy making. Two standard political parties that were active in parliament and also in government in the last decades were left before the threshold for the parliamentary seats. On the other hand, two new political parties were successful. One political party (some media called them movement) called "Sme rodina" (We are family) was presented within the same pattern that has been visible in the last decades in the campaigning and political

${ }^{1} \mathrm{PhDr}$.Viera Žúborová, PhD., Department of political sciences and European studies, Faculty of Social Sciences University of St. Cyril and Methodius in Trnava, Bučianska 4/A, 91701 Trnava, e-mail: viera.zuborova@ucm.sk.

${ }^{2}$ Mgr. Ingrid Borarosová, Department of political sciences and European studies, Faculty of Social Sciences University of St. Cyril and Methodius in Trnava, Bučianska 4/A, 91701 Trnava, e-mail: borarosova.ucm@gmail.com. 
practice in modern democracies, especially in Central and Eastern Europe. To be successful in the policy is to promote themselves as non-political actor, in other words promoting themselves as an apolitical candidate.

The other political unit was mediatized as an extreme right political party that celebrated the totalitarian Slovak states during the Second World War. "Extremism is fertile ground for radicals and the challenges for democratic forces" (Walter, 2016). Despite the fact that this political party was not visible within the public opinion research during the last few months it was able to get past the electoral threshold and gained more voters that the society and opinion research agencies imagined.

The main aim of this article is to analyse the distribution of votes within the Slovak republic and the position of this extremist party in society before the parliamentary elections, including the factors that "helped" this political party to enter parliament after the elections in March 2016. We assume that one of the main factors that influenced the success of the extremist political party was the actual situation within the migration crisis and the disillusion of the society with the standard parties in the political system and the level of distrust. On the other hand, we also assume that this movement was able to build up their position through online media. We believed that these online media were the driven force for their success.

\section{SIMPLE RHETORIC WITH SIMPLE EXAMPLES: THE MAIN WEAPON OF THE EXTREMIST}

If we observe the success of the extremist political party Kotleba-LSNS (KotlebaLudová strana Naše Slovensko = Kotleba-People's Party Our Slovakia) we need to analyse the main campaign pillars and the campaign manifesto. The political party stands on three main pillars, the first is the national pillar, the second is the Christian pillar and the third is the social pillar. The main "motto" of the political party is to eliminate the consequences of the crimes committed by the politicians after November 1989 and to establish social justice. The main slogan during the March elections was associated with the word "Order":

- "We will make order not only with the parasites in the settlements, but also with the thieves in ties."

- "Stricter penalties and jail sentence so that everyone, either the politicians or the parasites will think twice whether to prefer the honest work, or to steal and plunder."

- "With courage against the system." 
The order was also visible within the main electoral manifesto; it was divided into 10 main points. For example, there were calls to reduce the number of deputies in parliament, the opportunity for citizens to suspend MPs, the cancelation of state funding for political parties. The political party was also calling for the establishment of security forces, that would protect decent people everywhere, where the police have failed. These aims or goals were the most mediatized in society and also the most talked about in the media.

Image 1: Mediatization of political subject before the parliamentary election in Slovak republic in analyzed period $13^{\text {th }}$ of February to $28^{\text {th }}$ of February 2016

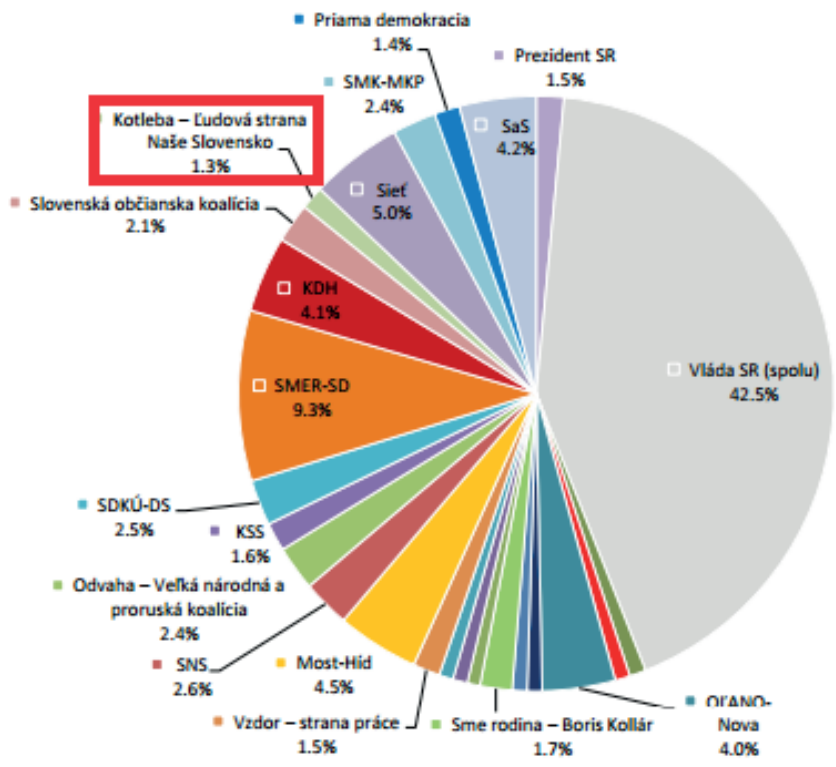

Source: Memo 98

On the other hand, the medialization of this political party was at the lowest level in comparison with the other relevant and competitive political subjects before the parliamentary election in March 2016 (see to compare Image No. 1). Despite the fact that all the relevant media houses held a strike against these movements and called up to obstruct their messages. The political party Kotleba-LSNS was positioned on the last place of the relevant mediatized political subjects with $1.3 \%$ of the media coverage. For example, the second parliamentary "youngster" after the election in March 2016 had media coverage 
of $1.7 \%$. Another example of non-mediatisation of this political subject was the same monitoring 2 weeks prior, where this political party was not visible at all.

This so-called media ignorance of the mentioned political party was on one hand influenced by the public research agencies, which were not able to measure the political preferences of this party, that could be relevant in the media. On the other hand, there was a dominant barrier which was visible within the relation to mediatize an extremist political party in the national media, or in other words "fear" to open Pandora's box and to "invite" and officially present the ideas of politicians, who were calling back to the totalitarian ways of the Slovak state during the Second World War. This ignorance was one of the main reasons why after the election in March 2016 "everybody was wondering why such a thing had happened" that an extremist party for the first time in the of the history of The Slovak Republic was successful and gained entry into the government.

\section{EFFECTIVE CAMPAIGN WITHOUT MEDIA COVERAGE}

If we consider the fact, that the media is currently the main factor for distributing the thoughts and ideas of political parties, it is questionable how this party could gain such a large following of support without significant medialization. "They are the main source of information for the public, they contribute to educate and provide the entertainment for their audience. The media in particular testify to the events with which the consumers may not have their own experience." (Walter, 2016)

As mentioned earlier the party did not gain any space in printed media, they used only television, social media and party meetings with their voters for their campaign. As Reschová stated it is currently highly possible that voter will face intensive activity of attractive verbal and nonverbal communication and will be forced to follow the controversial personal profiles of candidates in virtual world. (Filipec and Hurtikova, 2014) However, with regards to their activity in television, only one television station invited Kotleba for one of the first election debates and that was TA3, which caused the huge wave of criticism between other television stations. It was also the only television station which was streaming live press conferences from Kotleba's campaign. However, Kotleba's party was successful in the election so the other television stations could not continue with their tactic of ignoring this political party. Of course, we dare to doubt, if the fact that this party was ignored by the media was a contributing factor which in some way could have helped the party more than harm it, since the media, mainly the television was showing Kotleba mainly connected to the topic of migration and the 
Roma community, which are two very important and sensitive topics in the eyes of Slovak voters. Since the media did not portray Kotleba in reality, did not pose questions that were being asked of all the other standard parties, plenty of voters focused their attention mainly on these two topics, where Kotleba along with his parties offered somewhat unrealistic but very simple solutions.

If we think about their activities on social networks, this party always used mainly Facebook, which is often followed more than television or print media. Ludová strana Naše Slovensko had around 70,000 followers by 1.3.2016 (this number is still increasing) which makes them the second most successful party in Slovakia (first is $\mathrm{SaS}$ ). On Facebook, this party was campaigning and using rhetoric with simple mottos and status updates, which were renewed daily on their profile which offered solutions to the problems, which were mostly ignored by other political parties. Their statuses were frequented often with phrases in line with things such as, the fight against corruption, justice and equality, verdict of Brussel, members of parliament are thieves, we do not wish to have any migrant here, there has to be an order, petition against migrants, controllers in trains were successful, we have to put media in place, we will save money for Slovak citizens, gypsy terror and such dramatic headline status updates which were hard for people to ignore on social media. For the voters of the Kotleba's party it offered mainly the solutions to problems such as, the migration crisis, Roma problems and it also promised the fight against other political parties, which were only using the honest Slovak citizen. This activity on Facebook is according to the facts and relating to how many citizens actually voted for this party was a very successful strategy in gaining votes.

Other factors which helped Kotleba, in the elections were meetings. If we talk about the meetings before the elections, Kotleba's party officially visited 35 towns and villages for which he gained an audience of approximately 6000 citizens. However, Kotleba has been visiting towns and villages for many years, while he is also visiting "forgotten" such as places and areas which are not so attractive for other political parties since they do not consider their citizens as the potential voters, or they are too small to offer relevant political foundation or affect change. This tactic showed to be very functional especially during the election of the Banskobystrický self-governing district. Kotleba chose the same policy at these meetings as he had previously, that meant simple slogans and offers and promises to the citizens of that specific area which was needed and which people wanted to hear (for example, to stop gold mining in Podpol'anie).

Even when lots of post polls created before the elections, for example the ones for TV Markíza Focus agency denied that one of the main reasons 
why people choose to vote for Kotleba was the migration crisis, minority questions and the fight against standard political parties, we would state the opposite. In mentioned exit polls, it is stated that, on account of the migration crisis only $8.1 \%$ of his voters voted for him, while most importantly they considered the interests of Slovakia at $22.7 \%$, Anti-corruption program $20.3 \%$ and Social program $14.4 \%$. Ironically these three areas which were important for Kotleba's voters are directly connected to the reason which we have mentioned.

The migration crisis became one of the most discussed topics in the media. Even as we stated, Kotleba did not have as much media space as the other candidates, never ending promotion of this topic logically had to bring advantages for the party, which has been for years presenting itself with Eurosceptic politics and hostility against minorities. Since the classical presentation of the Slovak political parties is constantly looking for enemies, the governing party Smer, which is still the strongest party in Slovakia was helping to spread this topic and it was keeping it alive until the elections. Since this political party in the previous years did not deliver, many of voters decided to choose another alternative, which shows a similar orientation of the Slovak citizen as it was shown in the previous years by Smer.

Another topic why voters chose this party was the Anti-corruption program, which is the topic that can be used in the fight against the standard political parties. Kotleba already started with this orientation during his election to Banskobystrický self-governing district and continued with it even after he was elected. As the tool, he used mainly social media networks and regional news which were printed with the financial support of Banská Bystrica. For the propagation of his party he chose not only negative reference to politicians (1st point of their program is We will stop the state robbery), but he also used positive information such as, how he was able to decrease the debt of Banská Bystrica self-governing district and that his plan is to do exactly same throughout the whole of Slovakia. 
Table 1: Opinions of media editor on permission to presented political movement LS-NS

\begin{tabular}{|c|c|c|c|}
\hline Media & $\begin{array}{l}\text { Question n.1: How will } \\
\text { information about the } \\
\text { political party L'S-NS be } \\
\text { presented? }\end{array}$ & $\begin{array}{l}\text { Question n. 2: How } \\
\text { much space will be } \\
\text { offered to LS-NS to } \\
\text { comment on political } \\
\text { matters? }\end{array}$ & $\begin{array}{l}\text { Question n. 3: How } \\
\text { will you address the } \\
\text { LS-NS if you will be } \\
\text { mentioning it in your } \\
\text { media? }\end{array}$ \\
\hline Sme/print & We cannot ignore them & $\begin{array}{l}\text { We will not give them } \\
\text { space without good } \\
\text { reason }\end{array}$ & Extremist/Neo-Nazi \\
\hline $\begin{array}{c}\text { Denník N/ } \\
\text { print }\end{array}$ & We cannot ignore them & $\begin{array}{c}\text { It is not the obligation } \\
\text { of the media to offer } \\
\text { them same space }\end{array}$ & $\begin{array}{c}\text { Fascist/Neo-Nazi/ } \\
\text { Extremist }\end{array}$ \\
\hline Pravda/print & $\begin{array}{l}\text { We cannot give them } \\
\text { space }\end{array}$ & $\begin{array}{l}\text { We cannot give them } \\
\text { space }\end{array}$ & Extremist \\
\hline $\begin{array}{l}\text { Markíza - } \\
\text { TV }\end{array}$ & $\begin{array}{l}\text { We give space to all the } \\
\text { relevant parties }\end{array}$ & Everyone will get space & $\begin{array}{l}\text { We don't use the } \\
\text { names such as fascist } \\
\text { party in connection to } \\
\text { parliamentary parties }\end{array}$ \\
\hline RTVS- TV & $\begin{array}{l}\text { RTVS will act as they } \\
\text { did previously }\end{array}$ & $\begin{array}{l}\text { RTVS will act as they } \\
\text { did previously }\end{array}$ & $\begin{array}{l}\text { RTVS will act as they } \\
\text { did previously }\end{array}$ \\
\hline
\end{tabular}

Source: Medialne.etrend.sk

The third area is their social program. Since it is the party which is focused on middle and lower class, same as Smer, it is obvious that after so many years in Government without significant change there was a lot of frustration. That is why it is no surprise that Kotleba was popular especially in the areas with high unemployment and with areas with rising problems with Roma population. In both cases this political party offered a simple solution and that was to stop the dictating coming from Brussels, support and renewal of the economy, food and energy independence in Slovakia in all regions and creating an order with Roma minority, with the popular step of stopping benefits for people who do not wish to work. Since the media only shows what "black villages" they build, how much in benefits they are taking from the state and how much they bully the majority population it is logical that in areas where this situation is serious and not solved L'SNS found supporters easily.

According to the signs that were observe in analyse of the success of LS-NS in the parliamentary election we need to also analyse the election results. The 
analysis of preferential votes and media reports we can be able to read up the success of this political movement. Some analysts notice during the election night and also after the first results came up that distribution of votes for LS-NS were mainly from voters from "hungry valleys" in Slovakia (see closer Image NO 2. And compare with Image NO 3). It could be more than obvious that this political movement reacted on current political and societal situation in the country and also to increasing distrust towards mainstream political parties in the Slovak party system.

This distrust and scepticism helped this movement to the parliament. As it is obvious also by preferential votes of the leader of the political party LS-NS Marián Kotleba, he gained in total 156355 votes, 74, 53\% average preferential votes. But we also should notice in this article that the preferential votes that were gave to Marian Kotleba were in the contrast with the medialized information from political analysts. He was not only successful in the "hungry valleys" but also, he was able to received votes from capital cities and regional cities. On the other hand, the distribution of the votes showed up that with expectation of the Eastern part of Slovakia Marian Kotleba was able to received votes relatively distribute, mainly the regions in the Northern part of Slovakia (Kysuce and Orava) but also in the central part of Slovakia (Banska Bystrica region).

Image 2: Preferential votes for Marián Kotleba, party leader of Kotleba-L'SNS in the parliamentary election March 2016

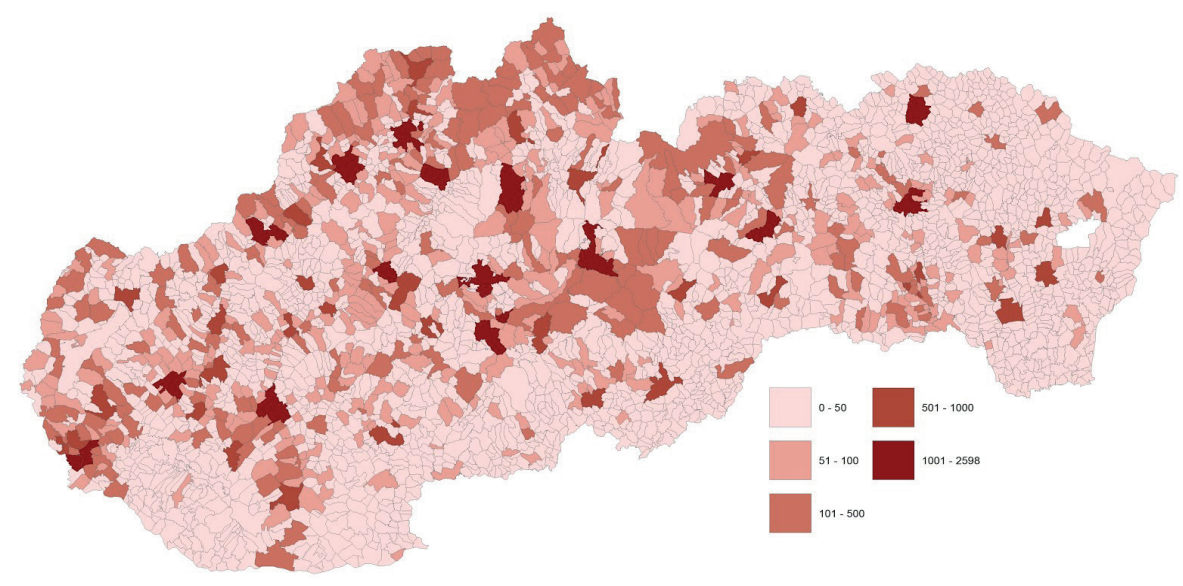

Source: authors own analyse 
Image 3: Received votes for political party L'S-NS in the parliamentary election March 2016

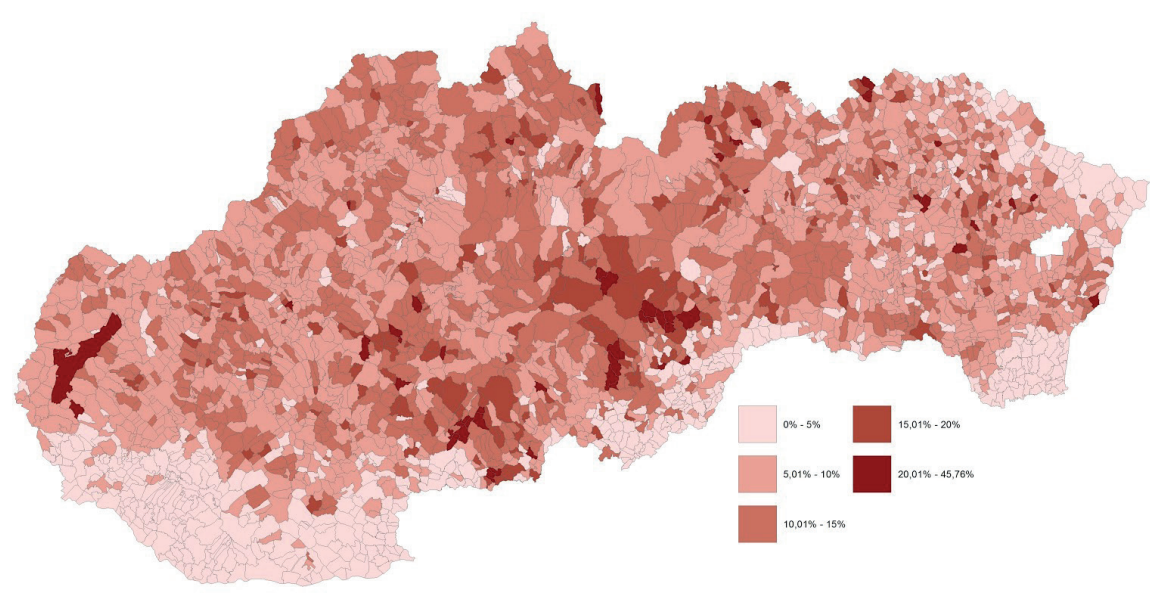

Source: authors own analyse

From the view of overall society mood and other events, which happened and were medialized shortly before or after elections, we can expect that medialization of this party (dominantly) in negative light will be increasing. However, we should realize one fact which is often forgotten by politicians and media and it is the influence of negative mediatization of the political subject towards society, since lots of researches from the past few years underlined the fact that negative advertising can lead to mobilization not depolitization.

So, what is the future development of the relation between the media and L'SNS? Since it is not a very standard topic of the media in relation to Kotleba which is very confusing. Was this topic ignored by the media because they did not consider it as a relevant political subject, which could answer the questions about the future political development in Slovakia, or was it disregarded mainly because it is an ultra-right subject and for this reason the media tried to push it into a political vacuum. The answer to this question could be found in the discussion created by Mediálne.sk, where its editor asked editors of print media and television three simple questions, which should reflect how this cooperation between them and Kotleba would develop in the future. The first question was about how the media will inform about the political party LSNS, the second question was if the media will request a reaction from them about political matters and the third question was how the media will address the political party L'SNS. (Poláš, 2016) 
From the table shown above we can clearly see that the media coverage, which was offered to this party will in the future probably be similar, so that means that they will obtain the minimum space in print media and some small part in television coverage. In any case, it is starting to be obvious that this tactic, of avoiding this political party, which supposed to lead to disregard from the people's side proved itself wrong. Even without relevant media coverage the party could carry and deliver its program to voters mainly with the help of social media networks. It is obvious, that since the media ignored this party and did not let it answer the common question which are usually asked from other political parties, it lead the party to the possibility of building their program on propagation of their strong topics. (Horváth and Švikruha, 2015)

\section{IF TRADITIONALS HATE ME, ONLINE WORLD WILL LOVE ME}

If the mainstream media are not able to give political (or social) movements space for their presentation, they find in the modern era another way of gaining visibility within society. Alternative media and online media are a prominent feature in the era of internet based information and are well known by the political actors. They became one of the key tools of how to target specific voters through the online campaigns.

Current scholars also believe, that the alternative and online media are able to provide visible and well-known position to some political (or social) movements that are ignored by the mainstream media. In the other words, new forms of media are able to offer the tools to attract mainstream media attention (Lester and Hutchins, 2009).

Graph 1: Media Coverage of L'S-NS (1.1.2016 - 5.3.2016)

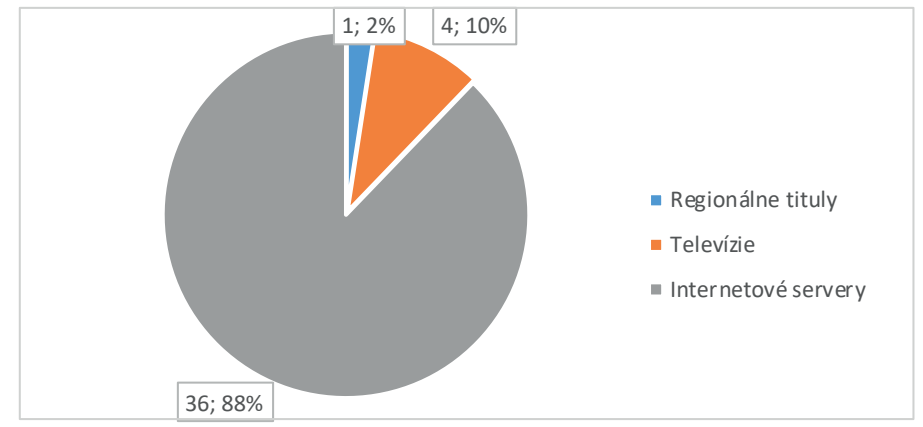

Source: authors own media monitoring 
We believed that this was also the case of the political movement L'S-NS. Their media coverage was dominantly represented by online (and alternative) media with minimum mainstream media. The main aim of this part of article is to analyse the media coverage of Marian Kotleba as the leader of LS-NS and also the media coverage of the political movement L'S-NS in the relation to their presentation during the official campaign period. The analysed period of the media coverage was from the $1^{\text {st }}$ January 2016 until the Election Day $5^{\text {th }}$ of March 2016. The coding was designed to collect the media messages, that had headings, keywords or content with the term "Kotleba" or "LS-NS".

When comparisons are made of these two analysed terms, we are able to state, that the level of personalization of politics also in this movements are massive, in relation to the media coverage. On one hand, it is also influenced by the fact that Marian Kotleba was holding (before and after the period of electoral campaign) the position of The Chairman of Banská Bystrica Region. In comparison, the visibility (media frequency) of Marian Kotleba was 19 times higher than his own political movement LS-NS (831 media messages of Marina Kotleba in comparison to 43 media messages of L'S-NS).

Despite the fact, that the chairman of the political movement was able to gain more media visibility (and that is in fact standard political logic) than that of his own political unit, we are able to notice some similarities in the media coverage, or even the types (and format) of their media coverage.

Graph 2: Media Coverage of Marian Kotleba (1.1.2016 - 5.3.2016)

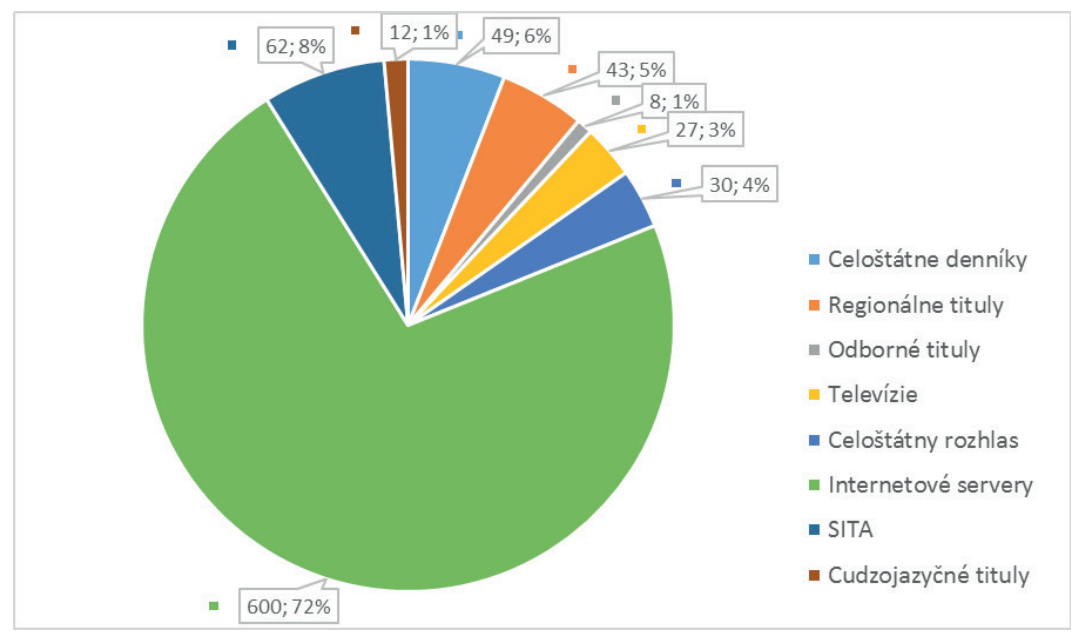

Source: authors own media monitoring 
The fundamental similarity is the fact that both - Marian Kotleba and also his own political movements L'S-NS are visible dominantly in online media with comparison to standard Slovak media.

On the other hand, the variety of media format and types also differs in the comparison of Marian Kotleba and LS-NS. Marian Kotleba in the analysed period was able to "receive" more personal media coverage than his party in a variety of regional and national media (print, online but also television). Media coverage of L'S-NS was in comparison with its leader in the variety of media types very low. In fact, in the case of Marian Kotleba it was more than $72 \%$ (600 media messages) and in the case of the political movement L'S -NS it was 36\% (36 media messages).

Graph 3: Media Coverage of Marina Kotleba at Slovak online media (1.1.2016 $-5.3 .2016)$

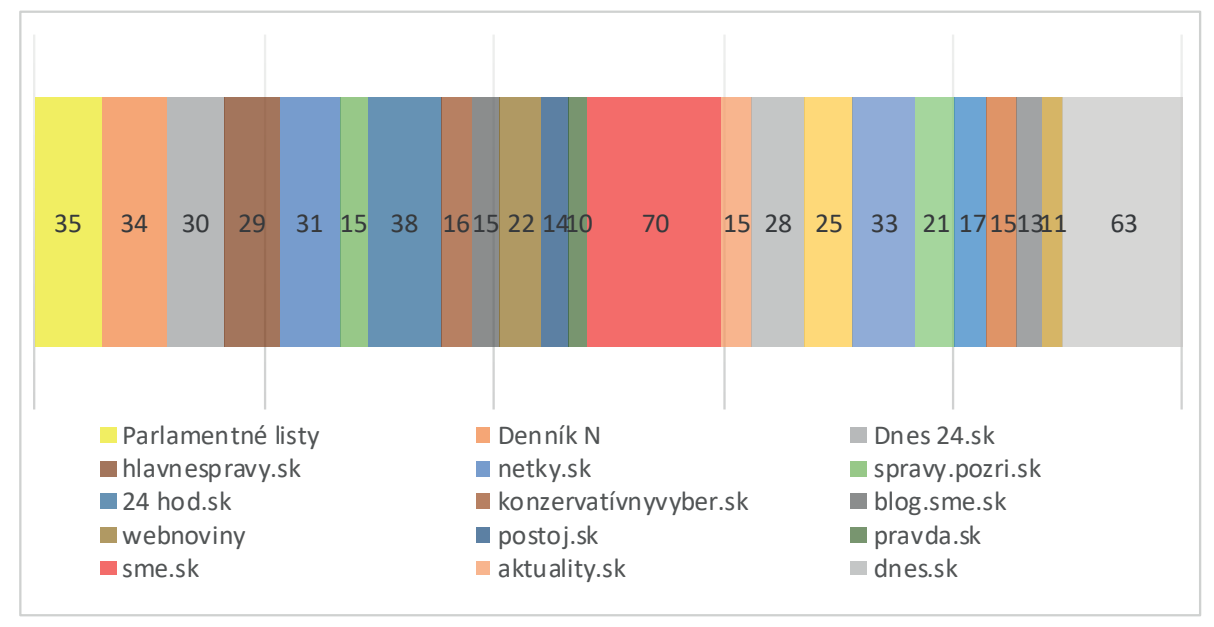

Source: authors own media monitoring

Also, when you look closer at the media coverage of Marian Kotleba online we are able to notice that there are also variety of online media types. Although on the other hand, not all of them could be called mainstream media or national online media. Some of them also gave members of Kotlebas political unit some space to promote the movement and the main pillars of the electoral manifesto.

There has been some tension between the mainstream media and Marian Kotleba and his political movement in the past, and these tensions hit back before the parliamentary election, when some media refused not only to speak about him 
and his movement, but also to inform about him and his movement and to give them space for self-presentation during the electoral campaign. Nevertheless, he was able to promote himself and also his political movement through alternative methods and online media. The political movement with his leaders was able to occupy the online sphere despite the fact that mainstream and well known media were calling for the blockade.

There is no statistical explanation, that this media coverage was the driving force of the election of Marian Kotleba and his movement into the parliamentary seats. However, there could be an explanation as to why he was able to get to parliament, despite the fact, that the mainstream and also relevant media refused to give him media coverage. The explanation is based on the power of online media.

We believe, and also some case studies around the world have shown and demonstrated that research conducted with regards to online spheres tends to not only open up questions and views that are completely or partly banned in the mainstream media. The results that were conducted by some scholars showed that the online sphere is a key tool for violent extremists to encourage others to adapt their views, but also that online media are competing with each other. (CTITF, 2011) And to raise the financial and PR account they tend to promote more and more values, ideas, views of individuals that are standing behind the moral and ethics borders of the modern societies. The internet and social networks are not only changing the moods and social behaviour of individuals, that are more active in the online world but also the way how the political actors compete between each other. To be more successful it makes you more vulnerable to the external world and more vulnerable to extremist and radical views and notions. This pattern could be applied also on the online media and their behaviour. They tend to give space for more non casual or nonstandard views because they need to have "clicks" to be able to survive in this competition. ${ }^{3}$

\section{CONCLUSION}

Online media is currently (and we can observe that also in this time period) the driving force of changes, not only at the societal level, including the fundamental behaviour of individuals, but also on the political level. Online media has become an effective tool for political parties to gain more potential voters. Still the internet and social media are an undiscovered environment also for the political actors and they are not still able to take advantage of the full potential of these

${ }^{3}$ For futher details refer to the following studies: Radicalization in the Digital Era (2013) by Behr, Reding, Edwards and Gribbon, Online Radicalization to Violent Extremism (2011) by COPS and Promoting Online Voices for Countering Violent Extremism (2013) by Helmus, York and Chalk. 
forms of information streams. Although there are moments when political elites and units are able to tap into this pot of gold and shut down all their concurrency in this online world.

The main aim of the article was show the reader the main danger, that is becoming very visible in these current times and that could lead to the success of extremist party in the past (March 2016 parliamentary election) but also in the future, if we do not become more wise and sensible in these areas of information.

The media analysis proved the current argument of some scholars and analysists that Marian Kotleba and political unit L'S-NS was able to occupy the media sphere through online content and online media despite the fact, that the mainstream medias were blocking them.

We are able to state the view that is well known also in other states and yet confirmed also through the research. Online media on one hand are able to raise violence, extremism and radicalism, including the ability to recruit similar radical and extremists, and on the other hand, they are vulnerable in their ability to cover also the extremist and radical views. The rationality of online media within their financial capital tends to lead them to "write" and give space to individual views, notions and values are behind the moral and ethical barrier of standard modern and democratic society. They need to have more readiness and the easiest and clearest way how to receive it is to promote and write about noncausal events, persons and subjects.

The parliamentary election in March 2016 confirmed the mood of Slovak society in the last decades and also the changes in their attitudes and behaviour which is not able to be explained only by the traditional theories, that are buried down. On the other hand, the parliamentary election showed that we are still seen as a society that is keeping their traditional authoritarian view on some moral and ethical questions. However, the parliamentary election showed greatly that this has shifted at the societal level. It showed that the position of online media could be crucial in the future developments and results of elections and political party success where any kind of view and attitudes could be directly targeted through online media. As the analysis of online media showed there is a visible trend to not only promote extremist and radical views but also to give space to political movements that are calling up these tensions in the society.

\section{REFERENCES}

BEHR, I., REDING, A., EDWARDS, C., GRIBBON L., (2013). Radicalisation in the digital era. RAND Europe. [online] Available at: http://www.rand.org/ content/dam/rand/pubs/research_reports/RR400/RR453/RAND_RR453.pdf 
[Accessed November 15, 2016].

COPS., (2011). Online Radicalization to Violent Extremism. [online] Available at: http:/www.theiacp.org/portals/0/pdfs/ radicalizationtoviolentextremismawarenessbrief.pdf [Accessed November $15,2016]$.

CTITF, (2011). CTITF Working Group on Use of the Internet for Terrorist Purposes. [online] Available at: http://www.un.org/en/terrorism/ctitf/ pdfs/ctitf_riyadh_conference_summary_recommendations.pdf [Accessed November 15, 2016].

FILIPEC, O., \& HURTÍKOVÁ, H., (2014). Medial reflection of Euro myths in the Czech Republic. Journal of Contemporary European Studies, pp. 45-86. [online] Available at: http://www.ces.upol.cz/wp-content/uploads/2014/12/ CES_1_14_Filipec-Hurtikova.pdf [Accessed May 15, 2016].

HELMUS, T., YORK, E., CHALK, P., (2013). Promoting Online Voices for Countering Violent Extremism. RAND Corporation. [online] Available at: http://www.rand.org/content/dam/rand/pubs/research_reports/RR100/ RR130/RAND_RR130.pdf [Accessed November 15, 2016].

HORVÁTH, P., ŠVIKRUHA, M., (2015). Impact of digital media to electoral behavior of citizens. Marketing Identity. Digital Life - part II., FMK, University of Ss. Cyril and Methodius in Trnava, Slovakia, pp. 370-377.

LESTER, L., HUTCHINS, B., (2009). Power games: Environmental protest, news media and the Internet. Media, Culture \& Society, 31(4), pp. 579-595.

POLÁŠ, M., (2016). Kotleba vs. médiá: Ignorovat', či tvárit' sa, že ide o bežných politikov? Medialne.trend.sk, [online] Available at: http://medialne.etrend. sk/tlac/kotleba-vs-media-ignorovat-ci-tvarit-sa-ze-ide-o-beznych-politikov. html [Accessed May 15, 2016].

RESCHOVÁ, J., (2011). Od volební kampaně k přímé volbě hlavy státu. Iuridica: Ústavni postavení prezidenta republiky a zpi̊sob jeho volby, pp. 63-72. [online] Available at: www.prf.cuni.cz/dokumenty-download/1404047095 [Accessed April 20, 2016].

WALTER, A., (2016). Institutional partisanship. Slovak Journal of Political Sciences, 16(2), pp. 146-16. 